\title{
A Gender Analysis of Women in Public-Private-Voluntary Sector 'Partnerships'
}

\begin{abstract}
The nature of work and traditional notions of the public sector have been changing with increasing collaborative governance and delivery of public services among public, private and voluntary sector organizations. In the UK, governments at national and devolved levels of government have adopted a collaborative governance approach to service delivery through various network and partnership arrangements. This paper explores these collaborative governance arrangements from a gender perspective, specifically the perceptions of women in public-private-voluntary sector partnerships. While previous research in this area have explored aspects of collaborative governance such as power, trust, accountability, decision making, performance, exchange of information and participation; there is very little research on women within these networks. The paper therefore provides a gendered analysis, disaggregating survey data to better understand the dynamics, for women, of collaborative governance and partnerships among public, private and voluntary sector organizations.
\end{abstract}

\section{Keywords}

gender, collaboration, partnerships, governance, networks 


\section{Introduction}

During the 1980s and 1990s there was a gradual shift from bureaucratic, hierarchical control and command public service delivery to markets, with scholars describing this as New Public Management (Hood, 1991; Massey and Pyper, 2005). Recently, we can observe more collaborative forms of service delivery through a combination of public, private and voluntary sector organizations. Public service delivery through collaboration is now so pervasive that O'Flynn (2009) argues there is a 'cult of collaboration.' Scholarly debate has followed suit with myriad of terms for collaboration such as partnerships, co-governance, coproduction, co-design, co-implementation, network governance, horizontal governance, etc. (see Voorberg et al, 2015; Carey and Dickinson, 2015). According to Cornforth et al (2015) collaborative governance is a formalized, joint-working arrangement between organizations that remain legally autonomous while engaging in on-going, coordinated collective action to achieve outcomes that none would have achieved independently. The definitions cover the spectrum of 'working together' (see Keast et al, 2012) with various co-productivities and partnership working among governmental and non-governmental sectors.

Scholars often employ network, resource dependency and institutional theoretical persepectives to explain collaborative organizational relations (Sowa, 2009). Network theorists argue that trust, reciprocity, the level of interdependence, shared norms, power, and leadership are important factors for successful inter-organizational working (Gazley, 2010). Resource dependency theorists would argue that collaboration stems from environmental constraints (ibid). In other words there is a need to secure resources to ensure that uncertainty and risk is reduced through collective inter-organizational working and sharing of resources 
(ibid). Institutional theorists argue that collaboration stems from the need to develop shared response to problems facing an organization and the need to sustain the organization (ibid). However, there is seldom a gender persective of collaborative governance. Indeed, Carey and Dickinson (2015) in their review of scholarly research of gender in public administration note a lack of attention paid to the issue and call for research in this area particularly with emerging discourse of greater inter-organizational working in an increasingly pluralist state. This paper will address the scholarly deficit and argue that collaborative governance, far from being collaborative, reinforces gender roles and patterns of behaviour through institutional isomorphism.

\section{A Gender Perspective}

Although there are various explanations for the under-employment and under-representation of women and paucity of female careers; much of the under-valuing of women in organizations can be traced to prejudicial sex-type roles assigned during socialisation (Nicholson, 1996). The social construction of male and female as biological sex categories results in gender categorisations of masculine and feminine in society (Nicolson, 1996). Gender is the way in which society organises lives in predictable patterns of behaviour such as division of labour (e.g. men being in paid employment as the provider and women as domestic and child carers), designation of resources, roles in public and private spheres, values and norms (Lorber and Farrell, 1991). Societal norms stratify male and female roles with men playing a more dominant role with resultant patriarchy (Walby, 1989). Gender relations are power relations through which masculine norms have superordinate status over feminine norms, and socialisation into gender roles is integral to the maintenance of patriarchal power structures (Nicolson, 1996). Patriarchy and gender norms are present in 
organizations as a microcosm of society. Organizations are structured along gender norms with practices and policies that perpetuate unequal power, rewards and opportunities, and interpersonal interactions that confirm and recreate gendered patterns of behaviour (Acker, 1998).

In society and organizations the sexual division of labour results in men being associated with power, reason and gendered masculine norms such as dominance and assertiveness (DuestLahti and Kelly, 1995). Men are therefore associated with masculism and in the sexual division of labour are associated with 'power duties' and benefit from more social power than females (ibid). Women, socialized as feminine, are stereotyped as caring, unassertive, interested in appearance, dependent, illogical, and home and family focused (Nicolson, 1996). The manifestations of masculine and feminine norms in organizations results in men being considered more suitable for managerial and leadership positions, i.e. positions of power. Rank in organizational hierarchies influences ideas of leadership with the highest levels occupied by men often displaying masculine qualities (Eagly and Carli, 2007). Male managers and leaders consider agentic traits such as assertiveness, competitiveness, drive, decisivenesss, achievement and action orientation to be requirements for success (ibid). By contract, women face prejudice which flows from the mismatch of the social contruction of femininity where women are expected to be nurturing, caring, communicative, 'soft', nice, kind and emotional (ibid). Thus, women are often perceived to have emotional intelligence, empathetic, cooperative and interdependent (ibid). Women who display masculine norms often face sanctions and discrimination from those within organizations (Duest-Lahti and Kelly, 1995; Eagly and Carli, 2007; Rhode, 2003). Thus, the path to managerial and leadership positions traverses gender norms and women often face a fraught trajectory to 
reach senior levels in organizational hierarchies. This is commonly referred to as the 'glass ceiling' with a vertical occupational gender segregation present in most organizations (Eagly and Carli, 2007; Davidson and Cooper, 1992).

When women enter paid employment and seek careers within organizations there are prejudices, sexual discrimination and harassment (Kelly, 1995), and the manifestation of sex roles with women assigned to stereotypical feminine roles (McTavish and Miller, 2006). Women are often concentrated in stereotypical feminine roles and professions such as nursing, education, care and voluntary (unpaid) work (Guy and Newman, 2004; McTavish and Miller, 2006; Beattie et al, 2005). This is referred to horizontal occupational gender segregation with a tendency for men and women to work in different occupations (Blackburn, Browne, Brooks and Jarman, 2003). Emotions are a mainstay of health and human service professions, public education, paraprofessional jobs, and most support positions such as administrative assistants, receptionists, clerical staff, and secretaries (Guy and Newman, 2004). Female employees are often expected and required to engage in emotional work to a greater degree than men, and women often respond to occupational expectations (Meier et al, 2006). The perception is that women, because of the social construction of gender, are most likely to be required to provide emotional labour in an organization (Guy and Newman, 2004). Guy and Newman (2004) argue that emotional labour is a missing link in the chain of events that produces lower wages for jobs held primarily by women. Thus, there is a conflation of gender roles with emotional labour that involves caring and results in work skills and abilities that are taken for granted, undervalued and not compensated (ibid). One can observe the horizontal occupational gender segregation has links to emotional labour because many female-dominated occupations (e.g. health and social care) are expected to 
employ emotional skills to bring about organizational ends, whereas male-dominated occupations are not (Meier, et al., 2006).

Evans et al (2014) in their research found that the cultural biases of women being primary carers for families results in organizational biases that favour those without family commitments. This results in organizational gender biases which assumes that women with children choose between families and careers (ibid). Women also have to fit into prevailing organizational culture particularly in 'male-streamed' government department (Evans et al, 2014:505). Evans et al (2014:506) also found that for women navigating to senior positions there was a masculine mobilization bias: a preference to 'clone people like us' which was reflected in perceptions of subjective recruitment practices; the perpetuation of 'boys' clubs' and limited support for women through government department networks; stereotyping women with children by assuming they are less committed and less reliable; intolerance for family-friendly work practices; and a disorted belief about women's capabilities.

Organizations place different expectations on men and women with those women who reach managerial and leadership positions often navigating masculine and feminine norms (Proudford, 2007). Proudford (2007) found that women employ a number of strategies to navigate their advancement within patriarchal organizational cultures. First, women have a tendency to downplay status differences preferring to focus on connectedness since emphasising status difference may appear arrogant or boastful (Proudford, 2007:435). Second, women's interpersonal relationships tend to be developmental, showing concern for others, establishing and maintaining mutuality in relationships (Proudford, 2007:436). A third distinction is women tend to focus on interpersonal relationship building while men emphasize the task at hand (Proudford, 2007:437). Thus, for men being perceived as 
competent, influential and powerful is highly desirable while for women being seen as likeable, nice and helpful is perceived to be valued (Proudford, 2007:438). The way in which men and women perceive they will be evaluated by the organization reinforces gender stereotypes of women being communal (Eagly and Carli, 2007) with emotional labour expectations (Guy and Newman, 2004). When women do display masculine norms such as assertiveness, this is often followed with criticism (Eagly and Carli, 2007), organizational sanctions and personal derogation (Heilman, 2001). Consequently women learn to follow a dominant organizational paradigm which reinforce gender roles (Bryans and Mavin, 2003). Thus, women conformed to the prevailing masculine organizational culture with unconscious organizational biases causing continued disavantage for women (Evans et al, 2014)

There are various organizational barriers to female employment and career progression such as prejudice, work-life balance, career breaks, part-time employment, performance evaluation, role expectations, etc. (see Kanter, 1977; Rhode, 2003; Karsten, 1994; Kellerman and Rhode, 2007; Heilman, 2001). The perception that women are not effectively networked as men reflects the dual role of women in paid employment as well as domestic roles. Women often have to balance work and life beyond work with caring responsibilities presenting obstacles to women in their careers and ability to build social capital (Eagly and Carli, 2007). Thus women rarely go after work for drinks or join in the weekend events particularly if they have domestic and child-care responsibilities (ibid). Networks, like organizations, tend to be male dominated with women usually having less legitimacy and influence and therefore may benefit less than men from participating in these networks (ibid). Social capital within networks enables men, relative to women, to develop their knowledge and better understanding of the organization and so navigate its norms, structure, culture and power relations for advancement (ibid). In the Evans et al (2014) study over half the women 
in male dominated government departments felt excluded from networks which they acknowledged was important to their career progression. Thus, within the organizational context there is an unconscious mobilization bias against women and is reflected in dominant norms and values that advantage men with the requisite attributes.

The next section of the paper turns the attention to collaborative governance to explore the gender dynamics which exist within networks of public, private and voluntary sector partnerships in the UK.

\section{Collaborative Governance in the UK}

In the UK recent government policy has attempted to engage local communities in a collective action with public organizations to achieve policy objectives (Bailey and Phil, 2015). The UK with a devolved political architecture has varied configurations of collaborative governance within each region. In England Local Enterprise Partnerships (LEPs) aim to engage local government, business and third sector stakeholders in partnerships towards local economic development (Department of Business, Innovation and Skills, 2010:5). One-hundred and fifty-three health and well-being boards were established in England with the aim to integrate health and social care through partnerships of local government, National Health Service (NHS), social care, children's services and community stakeholders (see Health and Social Care Act, 2012). In Wales there is an integration of public services through partnerships of public, private and voluntary sector organizations (Welsh Government, 2012). At local government level twenty-two local service boards were established to ensure joined-up service delivery among local government, other public bodies, and the voluntary and business sectors (Welsh Local Government Association, 2014). 
In the Welsh health sector, community health councils were established with the NHS, local government and voluntary and business sector stakeholders working in partnership to improve health outcomes (Welsh Government, 2007). In Scotland community planning partnerships, thirty-two in total, were configured in 2003 to ensure that local services are provided through governmental and non-governmental organizations with the aim of partnership working to provide better public services (Scottish Government, 2003). In 2014, health and social care were integrated in the form of a partnership between NHS Scotland, local government and voluntary and business sector stakeholders. Northern Ireland too has health and social care partnerships responsible for assessing and planning health and social care needs (Health and Social Care Northern Ireland, 2014). Since 2015 Northern Ireland has been reforming its local government to reflect partnership arrangements among various public and third sector organizations. Collaborative governance is observable throughout the UK and although there is variance in size, composition and statutory obligations; there are similarities with the involvement of public, private and voluntary sector organizations through networks to co-govern and co-produce public services.

\section{Research Design and Methods}

An online survey was disseminated to local government and health sector partnerships as the unit of analysis. The survey was sent to comparable partnerships: England LEPs $(\mathrm{N}=39)$ and health and wellbeing boards $(\mathrm{N}=153)$; Scotland community planning partnerships $(\mathrm{N}=32)$ and community health and care partnerships $(\mathrm{N}=31)$; Wales local service boards $(\mathrm{N}=22)$ and community health councils $(\mathrm{N}=8)$; and Northern Ireland health and care boards $(\mathrm{N}=5)$. Partnerships in Northern Ireland local government sector were not sampled at the time of the research as it was undergoing reform and being restructured. The survey was sent to the 
chairs or secretariats of the partnerships since they were more readily contactable (not all members of all partnerships were publically listed), and are at a more strategic decision making level of the partnerships. A total of 270 partnerships were sampled from a population of 290. The research involved randomised sampling, using Excel software, of community planning partnerships $(n=28)$, local enterprise partnerships $(n=38)$, health and wellbeing board $(n=140)$ and local service board $(n=20)$. It was decided to select the population, given the low number, of health and care board $(\mathrm{N}=5)$, community health and care partnerships $(\mathrm{N}=31)$ and community health councils $(\mathrm{N}=8)$. The overall research response rate was $56.2 \%$. The selection of comparable partnerships throughout the UK and response rate provided sufficient data for statistical analysis.

The survey included forty-four questions with the first eight questions involving discrete profile questions (e.g. gender, age, qualifications, sector and regional location of partnership). The next thirty-five questions explored collaborative governance with questions drawn form a review of literature with the conceptualisation of collaborative governance involving: working together, trust, interdependence, autonomy, shared purpose, and exchange of resources. The survey included five-point Likert scale questions to measure the extent of collaborative governance characteristics (see Appendix 1). The data was analysed, using SPSS, to disaggregate male and female responses and to conduct a cross-tabular and Pearson's correlation analysis of responses. There were 123 useable responses where respondents provided their sex categorisation with $38 \%$ and $62 \%$ of respondents being women and men, respectively.

There are limitations to the study that will have to be considered for future research. Firstly, the survey is based on a review of extant Anglo-Saxon literature of collaborative governance. 
Relatedly, the research was conducted in the UK with a particular polity context of devolved and collaborative governance in England, Scotland, Wales and Northern Ireland. Future research should explore the applicability and external validity of the research to other contexts. Indeed a comparative study of other countries and even between England, Scotland, Wales and Northern Ireland would be a valuable addition to scholarship of gender in public administration. A second limitation is that the research is mostly based on quantitative data. A qualitative study would enrich the research in this area and explore personal experiences of women and men within collaborative governance and how women navigate networks and organizational biases. Another limitation of the research was that the survey was disseminated to chairs or secretariats of partnerships. Future research should explore the experience of all members of collaborative governance to further investigate the gendered patterns of behaviour.

\section{Research Findings}

The gender disaggregation by sector of employment shows that most respondents were employed within the public sector (see Table 1). Irrespective of gender identification, the respondents tended to be predominately from the public sector. A second observation is that since the surveys were disseminated to chairs or secretariats of partnerships, one could conclude that $62 \%$ of men occupy this leadership role within the inter-organizational network.

[Insert Table 1: Gender Profile by Sector about there] 
A correlation analysis (Pearson's correlation coefficient; 0.01 alpha level; 2-tailed) of the data reveals statistically significant results. There were correlations between the variables of gender and trust among stakeholders in the partnership ( $\left.\mathrm{r}=.266^{* *} ; 0.01\right)$; information sharing among stakeholders $(\mathrm{r}=.214 * * ; 0.01)$; freedom to express opinion $\left(\mathrm{r}=.244^{* *} ; 0.01\right)$; collective decision making $\left(\mathrm{r}=.266^{* *} ; 0.01\right)$; belief that decisions within partnerships will benefit the community $\left(\mathrm{r}=.222^{* *} ; 0.01\right)$; belief that the performance of the partnership is monitored by government $\left(\mathrm{r}=.235^{* *} ; 0.01\right)$; risk to users of the service if the partnership fails to deliver $\left(\mathrm{r}=.253^{* *} ; 0.01\right)$; the partnership provides a better understanding of how to improve policy $\left(\mathrm{r}=.237^{* *} ; 0.01\right)$; participation adds legitimacy to decisions $\left(\mathrm{r}=.220^{* *} ; 0.01\right)$; and potential to make a difference in improving service delivery $(\mathrm{r}=.232 * * ; 0.01)$.

The correlation analysis taken in conjunction with the cross-tabulation from Tables 2 to 14 provide some observations about the dynamics of gender roles within partnerships. Table 2 reveals that there is a tendency for women, relative to men, to disagree that there is a high level of trust among stakeholders in the partnership and Table 6 shows that men are more likely to trust partners to deliver upon decisions. Women tend to disagree that they feel free to share information among stakeholders in the partnership (see Table 3). However, women tended to agree that they feel free to express their opinion in the partnership forum (Table 4), but tended to disagree that there was collective decision making in the partnership forum (Table 5). Women also disagreed that partnerships were efficient in terms of saving time by involving all stakeholders from the start of the process (Table 7). In addition, women tended to disagree with the statement that, 'I feel every stakeholder in the forum tries to make decisions which benefit the community /the public in general' (Table 9).

[Insert Tables 2 to 9 about here] 
Male respondents felt that partnership forums allowed for opportunities to network and build relationships with partners (Table 8). Men tended to agree with the statement that, 'I feel the performance of the partnership forum is monitored by government' (Table 10). They also tended to agree that: there is a high risk to users of the service if the partnership fails to deliver services (Table 11); the partnership forum has given them a better understanding of how to improve policy and service delivery (Table 12); their participation in the partnership adds legitimacy to decisions made by the forum (Table 13); and they feel that they make a real difference to improving the delivery of services in my community (Table 14).

[Insert Tables 10 to 14 about here]

\section{Discussion}

The research found that it is mostly men who hold leadership positions within the collaborative governance networks. This is consistent with extant research of the dominance of masculinity within organizations and men in leadership positions (Duest-Lahti and Kelly, 1995; Eagly and Carli, 2007; McTavish and Miller, 2006; Nicolson, 1996; Walby, 1989). This is despite the fact that in the UK women constitute $53 \%$ of civil servants, the majority of women are in administrative positions, with $36 \%$ of senior managers being women, and a significant number of female employees in part-time in the civil service (20\% compared to $4 \%$ of men) (Office of National Statistics, 2013). In local government in the UK, in 2010, there was 2,244,400 staff employed in the 375 local authorities in England and Wales with $75.1 \%$ of women being employed within the sector and $53.5 \%$ working on a part-time basis (Local Government Group, 2010). Yet only $24 \%$ of women are local government chief 
executives (Centre for Women and Democracy, 2014). In the NHS, 77\% of the workforce is women with $41 \%$ of chief executives being female (NHS Employers, 2014). In the UK women constitute $68 \%$ of the voluntary sector workforce (National Council for the Voluntary Sector, 2012). Thus, despite the high number of female employees within the public and voluntary sectors of the UK, even within networks of collaborative governance, women do not hold leadership positions of these partnerships.

Thus, we can observe that despite the high proportion of female employment in the public sector and the relatively high rate of public sector representation in these partnerships, it is still men who hold leadership positions within these networks. The research also revealed gendered patterns of employment with relatively more women representing the voluntary sector in the partnerships. Thus one can observe horizontal occupational gender segregation within collaborative governance with women assuming emotional labour roles (Guy and Newman, 2004) concentrated in stereotypical feminine professions such as health and social care. The research reveals both horizontal and vertical occupational gender segregation within the inter-organizational networks. Although partnerships offer the opportunity for respective organizations to nominate employees to represent the organization in the collaborative governance arrangement, it appears that collaborative governance mirrors the organizational gendered patterns and biases with men assuming power duties within these networks. The partnerships therefore represent an institutional isomorphism of the original organization within collaborative governance.

Male respondents felt that could make a real difference to improving services to communities. This is consistent with observed gendered male norms within organizations such as displaying agentic behaviours of influence, assertion, control, self-confidence (Eagly 
and Carli, 2007) and being the benevolent provider (Nicolson, 1996). Men also felt more responsibility for risk and responsiveness to government. This may once again refer to agentic behaviours of men responding to organizational expectations of performance and achievement orientation.

There were statistically significant differences between men and women on trust. There appears to be less trust of partnerships by women than men. For example, women tended to disagree that there is trust; sharing of information within the partnerships; collective decisionmaking; and that stakeholders within the partnership make decisions to benefit the community. Whereas men were more likely to trust partners to deliver upon decisions made within the partnership forum. Once again it could be argued that men are assuming agentic roles or assertive behaviours that decisions as decided by the leadership would be implemented. A possible explanation for the findings of trust is that gender norms manifest in women trusting the male dominated partnership less. The research by Proudford (2007) on how women navigate the gender norms within organizations may account for this finding. Women may be less trusting of the male dominated partnerships. They may have to employ strategies such as status deference, mutuality working and interpersonal relationship building, which are often not reciprocated (Proudford, 2007) to navigate collaborative governance and consequently may be less trusting of men in these partnerships. Thus, women are conforming to the prevailing masculine organization culture (Evans et al, 2014) and organizational expectations (Meier et al, 2006) within these partnerships, which for women is causing a level of distrust. 
Yet women did feel free to express their opinion within the partnership, but disagreed that there was collective decision making. A possible explanation is that women are employing communal and interpersonal skills (Eagly and Carli, 2007), but that their input may not necessarily be taken on board in collective decision-making given the male dominance of the partnership. It would be assumed that communal and interpersonal skills would be valuable in the network of joint working, but appears not to be the case. The finding supports Guy and Newman's (2004) research that emotional labour is under-valued in organizations. Interestingly, women tended to disagree that partnerships were efficient in terms of saving time by involving all stakeholders from the start of the process. The extant research does not offer an explanation for this and further research, preferably qualitative, would add value to understanding this finding. A possible explanation is that women may believe, given the low levels of trust, that public sector hegemony of the partnership may render the inclusion of stakeholders, particularly from the voluntary sector with a high level of female employment, tokenistic. Some qualitative statements in the survey responses hint to this. For example, a female respondent stated that: 'Community reps often feel their presence is tokenistic due to lack of knowledge of topics covered, lack of knowledge of processes involved...Community reps usually have limited knowledge of council, government processes due to being from outside the "professional" organizations involved.'

Male respondents felt that partnerships offered an opportunity to network and improve their understanding of the policy process. Furthermore, male respondents felt that their participation added legitimacy to the partnership. These findings are consistent with Eagly and Carli (2007) research that men have a greater opportunity to build social capital and contribute to their knowledge of the organization creating more opportunities for legitimacy and influence (ibid). Thus, within a network of collaborative governance gendered patterns of 
behaviour persist with men, relative, to women gaining more advantage from networked interactions.

The research presents a number of implications for the lack of representation of women in public administration and collaborative governance. Firstly, it erodes notions of representative governance. If an organization, particularly one which is involved in public policy and public service provision is not considered to be representative of the population it serves, it undermines notions of legitimacy and democratic principles. Citizens may have a legitimate concern that partnerships which are not representative of the population it serves could be trusted to deliver upon policy decisions and public services in the interests of society as a whole. A second implication is that if collaborative governance is not representative of the population, then societal interests would not necessarily be included in a policy process. Thus, there is an input deficit in collaborative governance which would affect the quality of policy decision making.

The lack of female representation and voice in collaborative governance has implications for the quality of decision making as well as the performance of the partnership organization. There is empirical evidence that more representative public administrations are better performing organizations. Pitts $(2005 ; 2009)$ found that more representative bureaucracies had higher levels of job satisfaction which impacted upon organizational performance. Andrews, Ashworth and Meier (2014) found that more representative UK fire authorities tended to be more effective organizations. Peters et al (2015) also found that a representative bureaucracy improved quality of organizational output. This is explained by the fact that diverse bureaucrats contribute a diverse set of skills, knowledge and experience to the organization (ibid). Peters et al (2015) argue that there is a positive association between 
workforce diversity and overall organizational performance. A longitudinal study by Fernandez and Lee (2016) of the South African national public administration departments from 2006 to 2013 found that public organizations, which were more representative of the population in a post-apartheid dispensation, achieved a higher percentage of organizational goals. They found empirical evidence that more representative public administrations were more effective organizations (ibid). Similarly, Riccucci (2002) and Bradbury and Kellough (2008) argue that more representative bureaucracies tended overall to be better performing organizations. More representative public administrations have improved service delivery outcomes for the public it serves (see Brudney, Herbet and Wright, 2000; Dolan, 2000; Hindera, 1993; Keiser et al, 2002; Meier, 1975; Riccucci, 1987; Thielemann and Stewart, 1996; Weldon, 2002; Wise, 2003). For example, Meier, Wrinkle and Polinard (1999) found that in 350 school districts in the US both minority and non-minority students perform better in the presence of a representative bureaucracy. Research by Wilkins (2006) and Wilkins and Keiser (2004) found that female child support enforcement supervisors represented female clients who directly benefitted from increased child support collections. Meier and Nicholson-Crotty (2006) in their research on the representation of women in police forces found that female police officers represented women as victims of sexual assaults. The police forces with higher rates of female representation saw a higher rate of arrests for sexual assaults (ibid). Meier and Nicholson-Crotty (2006:858) concluded that women shared a set of values about the seriousness of sexual assaults because they had a common set of gender related experiences. A similar study by Andrews and Johnston Miller (2013) empirically proved that where there were higher levels of female representation in English police forces there was a higher arrest rate for domestic violence. Collectively the research on representative bureaucracies demonstrated that the more representative the public organizations, the higher the possibility of improved service delivery, particularly for 
unrepresented or minority groups. Thus, unrepresentative collaborative governance similarly would have implications for the quality of decision-making and level of organizational performance.

Collaborative governance demonstrates a trajectory of a plural or pluralist state (Osborne, 2010). In the UK recent policy developments such as increasing the role of LEPs in public service delivery at local level (PWC and Smith Institute, 2015) with an increased allocation of funding to these partnerships (from 2014 to 2015 LEPs have been allocated $£ 7.6778$ billion from the UK government Growth Fund in addition to $€ 6.6544$ billion from the EU funding). This represents a considerable amount of investment in the local economy through collaborative governance. Yet there remains lack of representation of women in these partnerships. The implication of which is not only women's exclusion from collaborative governance, but as beneficiaries of public services as well. What is at stake is a shift of public services to collaborative governance with a considerable amount of public funding, yet women remain unrepresented.

A number of propositions can be drawn from the study and explored for future research. The first proposition is that within networks and collaborative governance gendered patterns of behaviour and biases persist. The second proposition is that these gendered patterns of behaviour are present, beyond the just the UK, in an international context as well. A third proposition is collaborative forms of governance will increase with the rise of pluralist state (see Carey and Dickinson, 2015) reinforcing gendered patterns of behaviour. A fourth proposition is qualitative research will also reveal the unconscious mobilization bias against women in collaborative governance (see Evans et al, 2014). A final proposition is that the 
lack of female representation in collaborative governance and input in policy decisions will impact upon the quality of public service delivery.

\section{Conclusion}

The study addresses a research deficit of exploring gender relations within collaborative governance, which has become an increasing feature or a 'cult of collaboration' of public service delivery. The research revealed that existing gendered patterns of behaviour and biases within organizations manifest in networks. Thus, we can observe norms of masculinity and femininity with agentic and communal behaviours, respectively, within the partnerships and an unconscious organizational bias against women. This is unsurprising, but revealing that despite the fact that collaborative governance offers the opportunity within a network for respective organizations to nominate representatives, vertical and horizontal occupational gender segregation persists. The findings suggest that these collaborations are far from collaborative or indeed partnerships. The collaborative governance is an isomorphism of the organizations and perpetuates gendered biases, values and behaviours. Thus, rather than being a new way to deliver public services or opportunities for increased representation and inclusion, collaborative governance continues the patterns of organizational biases with male dominance and female subordination. It remains questionable whether collaborative governance is truly taking place within these networks since there is a lack of equal representation and influence among all stakeholders in the delivery of public services. This has implications for the quality of policy decision-making within partnerships and improved service delivery. 


\section{References}

Acker, J. (1998) 'The Future of Gender and Organizations: connections and boundaries', Gender, Work and Organizations, 5,4, 195-206.

Andrews, R. and Johnston Miller, K. 2013. 'Representative Bureaucracy, Gender and Policing: The Case of Domestic Violence Arrests', Public Administration, 91, 4, 9981014.

Andrews, Ashworth and Meier (2014) 'Representative Bureaucracy and Fire Service Performance', International Journal of Public Management, 17, 1, 1-24.

Bailey, N. and Phil, M. (2015) 'Can the state empower communities through localism? An evaluation of recent approaches to neighbourhood governance in England', Environment and Planning C: Government and Policy, 33, 2, 289 - 304.

Beattie, R., Miller, K., Ogden, S., McTavish, D. and McKean, L. (2005) Gender Balance in Management: The Voluntary Sector in Scotland, Glasgow: Glasgow Caledonian University.

Blackburn, R.M., Browne, J., Brooks, B. and Jarman, J. (2003) 'Explaining Gender Segregation', The British Journal of Sociology, 53, 4, 513-536.

Bradbury, M.D., and Kellough, J.E. (2008) 'Representative bureaucracy: Exploring the potential for active representation', Journal of Public Administration Research and Theory, 18, 697-714.

Brudney, J.J, Herbert, F.T and Wright, D.S. (2000) 'From Organisational Values to Organisational Roles: Examining Representative Bureaucracy in State Administration', Journal of Public Administration Research and Theory, 10, 3, 491-521.

Bryans, P. and Mavin, S. (2003) 'Women Learning to Become Managers: Learning to Fit in or Play a Different Game?', Management Learning, 34, 1, 111-134. 
Carey, G. and Dickinson, H. (2015) 'Gender in public administration: looking back and moving forward', Australian Journal of Public Administration, 74, 4, 509-515.

Centre for Women and Democracy (2014) Sex and Power. Retrieved November 19, 2015, from Hansard Society: http://www.hansardsociety.org.uk/wpcontent/uploads/2014/08/Sex-and-Power-2014.pdf

Cornforth, C. H. (2015) 'Nonprofit-Public Collaborations: understanding governance dynamic', Nonprofit and Voluntary Sector Quarterly, 44, 4, 775-795.

Davidson, M.J. and Cooper, C.L (1992) Shattering the Glass Ceiling: The Woman Manager, London: Paul Chapman Publishing.

Dolan, J. (2000) 'The Senior Executive Service: Gender, Attitudes, and Representative Bureaucracy', Journal of Public Administration Research and Theory, 10, 3, 513-529.

Duest-Lahti, G. and Kelly, R.M. (1995) Gender, Leadership and Governance, Ann Arbor: University of Michigan Press.

Eagly, A. and Carli, L.L. (2007) Through the Labyrinth: the thruth about how women become leaders, Boston: Harvard Business School Press.

Evans, M., Edwards, M., Burmester, B. and May, D. (2014) 'Not Yet 50/50 - Barriers to the Progress of Senior Women in the Australian Public Service', Australian Journal of Public Administration, 73, 4, 501-510.

Fernandez, S. and Lee, H. (2016) 'The transformation of the South African Public Service: exploring impact of racial and gender representation on organizational effectiveness', Journal of Modern African Studies, 54, 1, 91-116.

Gazley, B. (2010) 'Linking Collaborative Capacity to Performance Measurement in Government-Nonprofit Partnerships', Nonprofit and Voluntray Sector Quarterly, 39, 4, 653-673. 
Guy, M. and Newman, M.A. (2004) 'Women's Jobs, Men's Jobs: Sex Segregation and Emotional Labor', Public Administration Review, 63, 4, 289-298.

Heilman, M.E. (2001) 'Description and Prescription: How Gender Stereotypes Prevent Women's Ascent Up the Organizational Ladder', Journal of Social Issues, 57, 4, 657-674. Hindera, J. J. (1993) 'Representative bureaucracy: Further evidence of active representation in the EEOC district offices', Journal of Public Administration Research and Theory, 3, October, 415-430.

Hood, C. (1991) 'A Public Management for All Seasons?' Public Administration, 69, 1, 3-19. Kanter, R.M. (1977) Men and Women of the Corporation, New York: Basic Books.

Karsten, M.F. (1994) Management and Gender: issues and attitudes, Westport, Conn.: Praeger.

Keiser, L.R., Wilkins, V.M., Meier, K.J. and Holland, C. (2002) 'Lipstick and Logarithms: Gender, Institutional Context, and Representative Bureaucracy', American Political Science Review, 96, 3, 553-564.

Keast, R. and Mandell, M. (2012) 'The collaborative push: moving beyond the rhetoric and gaining evidence', Journal of Managing Governance, 18, 9-28.

Kellerman, B. and Rhode, D.L. (2007) Women and Leadership: the state of play and strategiesfor change, San Francisco, CA: Jossey-Bass.

Kelly, R. (1995) 'Offensive Men, Defensive Women: sexual harassment, leadership and management' in G. Duerst-Lahti and Kelly, R.M. (eds.) Gender, Leadership and Governance, Ann Arbor: University of Michigan Press.

Local Government Group (2010). Local Government Demographics. Retrieved November 19, 2015, from Local Government Demographics: http://www.lgps.org.uk/lge/aio/18618151

Lorber, J. and Farrell, S.A. (1991) The Social Construction of Gender, New York: Sage. 
Massey, A. and Pyper, B. (2005) Public Management and Modernization in Britain, Basingstoke: Palgrave Macmillan.

McTavish, D. and Miller, K. (2006). Women in Leadership and Management, Cheltenham: Edward Elgar.

Meier, K.J. (1975) 'Representative Bureaucracy: An Empirical Analysis', The American Political Science Review, 69, 2, 526-542.

Meier, K.J. and Nicholson-Crotty, J. (2006) 'Gender, Representative Bureaucracy, and Law Enforcement: The Case of Sexual Assault', Public Administration Review, November/December, 850-860.

Meier, K.J., Wrinkle, R.D. and Polinard, J.L. (1999) 'Representative Bureaucracy and Distributional Equity: addressing the hard questions', Journal of Politics, 61, 4, 1025-1039.

Meier, K.J, Mastracci, S.H and Wilson, K. (2006) 'Gender and Emotional Labor in Public Organizations: An Empirical Examination of the Link to Performance', Public Administration Review, 66, 6, 899-909.

National Council for the Voluntary Sector (2012) Who Works in the Voluntary Sector. Retrieved November 19, 2015, from National Council of the Voluntary Sector: http://data.ncvo.org.uk/a/almanac12/who-works-in-the-voluntary-sector/ NHS Employers (2014) Women in the NHS. Retrieved November 20, 2015 from NHS Employers: http://www.nhsemployers.org/case-studies-and-resources/2014/03/women-inthe-nhs-infographic.

Nicolson, P. (1996) Gender, Power and Organization, London: Routledge.

Office of Government Equalities (2010) Women's Representation. Retrieved November 19, 2015, from Government Equalities Office: http://webarchive.nationalarchives.gov.uk/20100505211508/http:/www.equalities.gov.uk/ pdf/301611_GEO_WomensRepresentation_acc.pdf 
Office of National Statistics (2013) Office of National Statistics. Retrieved November 19, 2015, from Civil Service Statistics: http://www.ons.gov.uk/ons/rel/pse/civil-service$\underline{\text { statistics/2013/sty-civil-service-statistics.html }}$

O'Flynn, J. (2009) 'The cult of collaboration in public policy', Australian Journal of Public Administration, 68, 1, 112-116.

Osborne, S. (ed.) (2010) The New Public Governance? Emerging perspectives on the theory and practice of public governance, London: Routledge.

Peters, B. Guy, Schröter, E. and von Maravic, P. (eds.) (2015) Politics of Representative Bureaucracy: power, legitimacy and performance, Cheltenham: Edward Elgar.

Pitts, D.W. (2005) 'Diversity Representation and Performance: Evidence About Race and Ethnicity in Public Organisations', Journal of Public Administration Research and Theory, 15, 4, 615-631.

Pitts, D.W. (2009) 'Diversity management, job satisfaction and performance: evidence from US federal agencies', Public Administration Review, 69, 2, 328-338.

Proudford, K. (2007) 'Isn't She Delightful?: creating relationships that get women to the top (and keep them there)' in B. Kellerman and D.L. Rhode (eds.) Women and Leadership: the state of play and strategies for change, San Francisco: John Wiley \& Sons, pp. 431451.

PWC and Smith Institute. (2015). Delivering Growth: what next for LEPs. London: PWC.

Rhode, D. (2003). The Difference 'Difference' Makes: women and leadership, Stanford: Stabdford University Press.

Riccucci, N. (2002) Managing Diversity in Public Sector Workforces, New York: Westview. Sowa, J. (2009) 'The Collaboration Decision in Nonprofit Organizations: views from the front line', Nonprofit and Voluntary Sector Quarterly, 38, 6, 1003-1025.

Thielemann, G.S. and Stewart, J. (1996) 'A Demand-Side Perspective on the Importance of 
Representative Bureaucracy: AIDS, Ethnicity, Gender, and Sexual Orientation', Public Administration Review, 56, 2, 168-173.

Voorberg, W., Bekkers, V. and Tummers, L. (2015) 'A Systematic Review of Co-Creation and Co-Production: embarking on social innovation journey', Public Management Review, $17,9,1333-1357$

Walby, S. (1989) 'Theorizing Patriarchy', Sociology, 23, 2, 213-234.

Weldon, S. (2002) 'Beyond Bodies: Institutional Sources of Representation for Women in Democratic Policymaking', The Journal of Politics, 64, 4, 1153-1174.

Wilkins, V. M. (2006) 'Exploring the Causal Story: Gender, Active Representation, and Bureaucratic Priorities', Journal of Public Administration Research and Theory, 17, January, $77-94$.

Wilkins, V.M. and Keiser, L.R. (2004) 'Linking Passive and Active Representation by Gender: The Case of Child Support Agencies', Journal of Public Administration Research and Theory, 16, 87-102.

Wilkins, V., and B. Williams. (2008) 'Black or Blue: Racial Profiling and Representative Bureaucracy', Public Administration Review, 68, 4, 654-664.

Wise, L.R. (2003) 'Representative Bureaucracy’, in B.G. Peters and J. Pierre (2003) Handbook of Public Administration, Thousand Oaks, California: Sage. 
Table 1: Gender Profile by Sector

\begin{tabular}{|l|l|l|l|}
\hline Women & N & \% within Sample & \% within Gender \\
\hline Public Sector & 29 & $24 \%$ & $62 \%$ \\
\hline Private Sector & 3 & $2 \%$ & $6 \%$ \\
\hline Voluntary Sector & 12 & $10 \%$ & $26 \%$ \\
\hline Non Response & 3 & $2 \%$ & $6 \%$ \\
\hline Total & 47 & $38 \%$ & $100 \%$ \\
\hline Men & & & $66 \%$ \\
\hline Public Sector & 50 & $41 \%$ & $14 \%$ \\
\hline Private Sector & 11 & $9 \%$ & $13 \%$ \\
\hline Voluntary Sector & 10 & $8 \%$ & $4 \%$ \\
\hline Non Response & 3 & $2 \%$ & $3 \%$ \\
\hline Individual citizen & 2 & $2 \%$ & $100 \%$ \\
\hline Total & 76 & $62 \%$ & \\
\hline
\end{tabular}


Table 2: There is a high level of trust among the stakeholders in the partnership forum

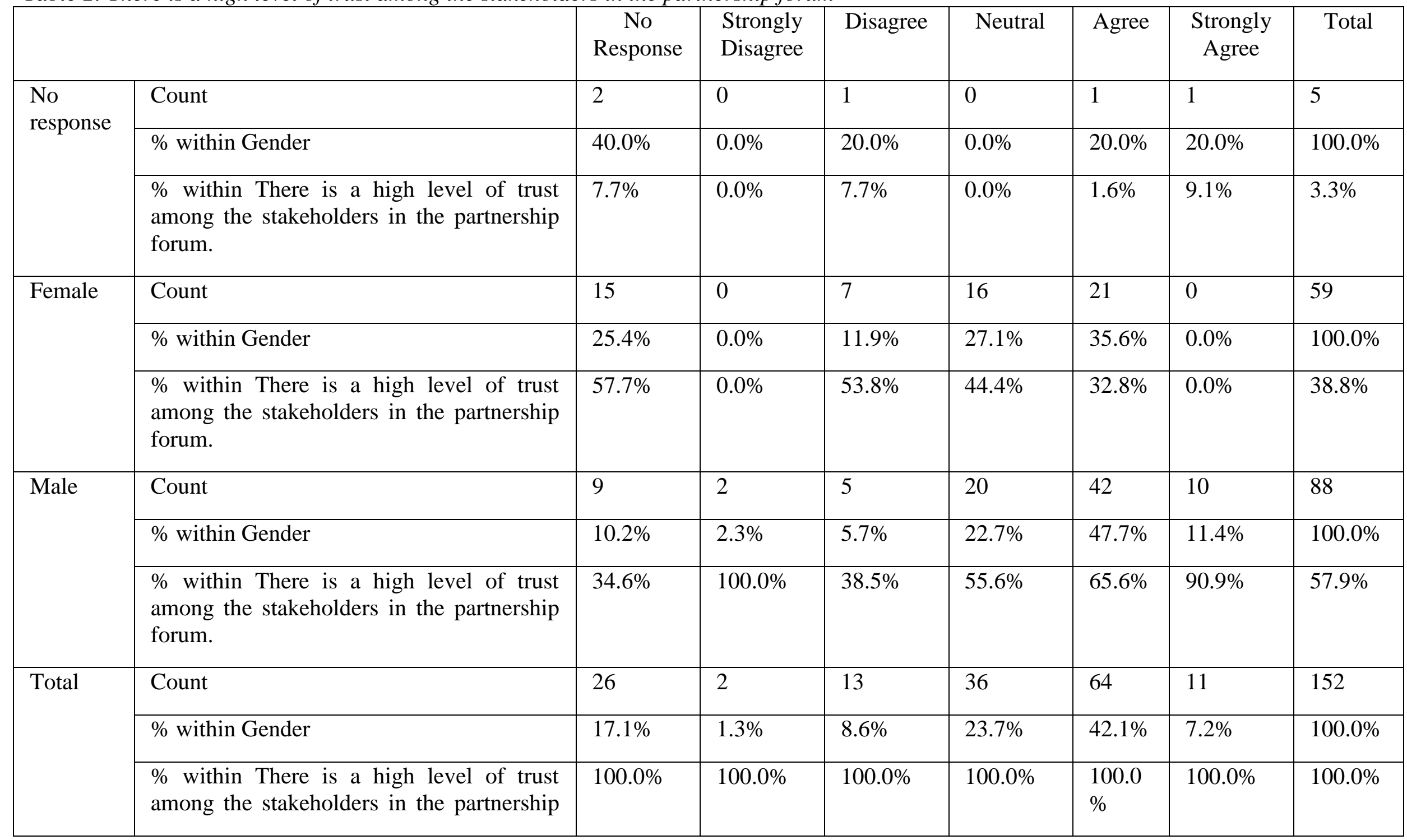




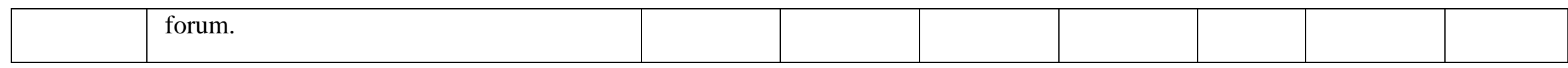

Table 3: I feel free to share information with stakeholders in the partnership forum

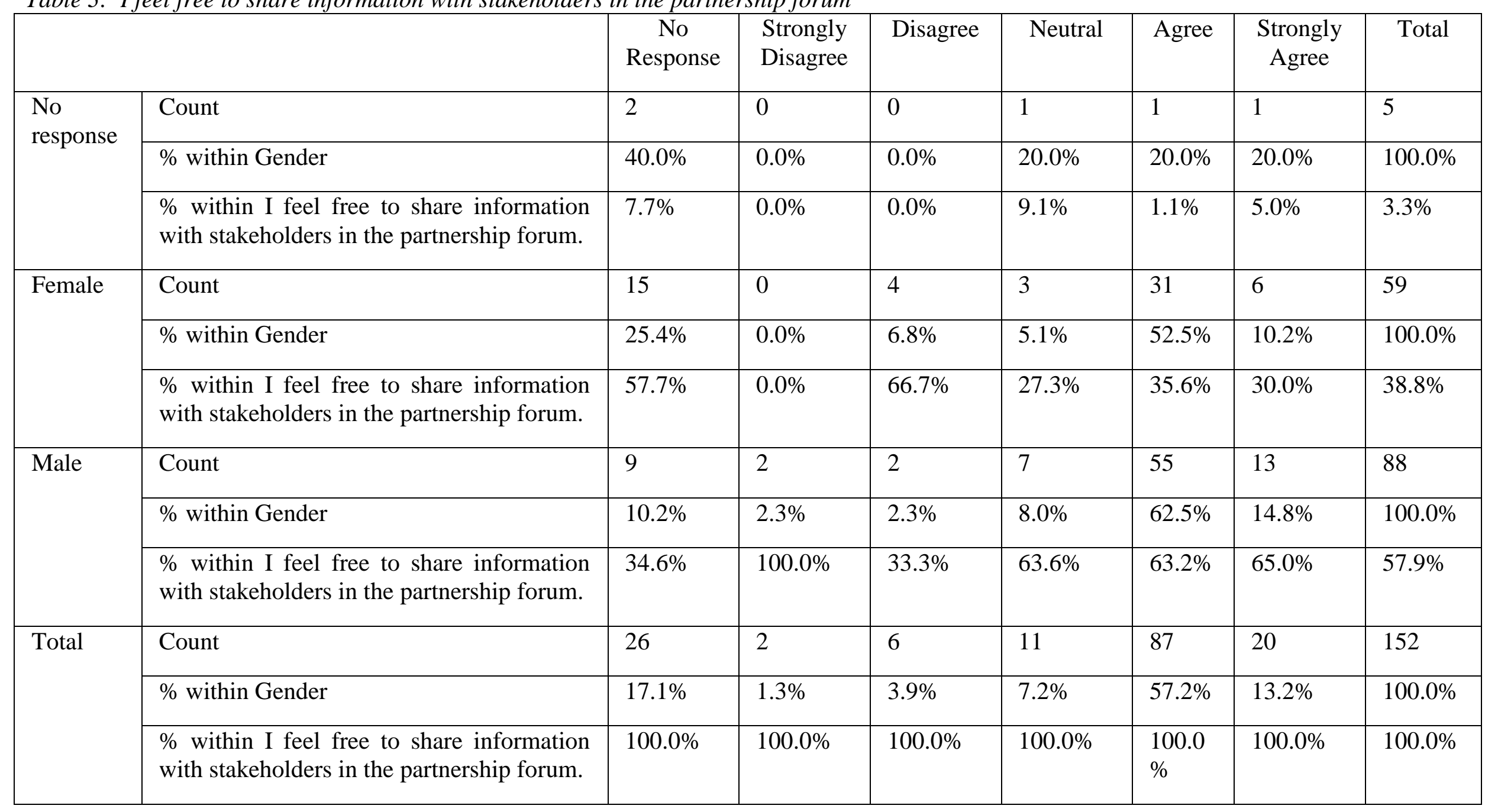


Table 4: I feel free to express my opinion in the forum

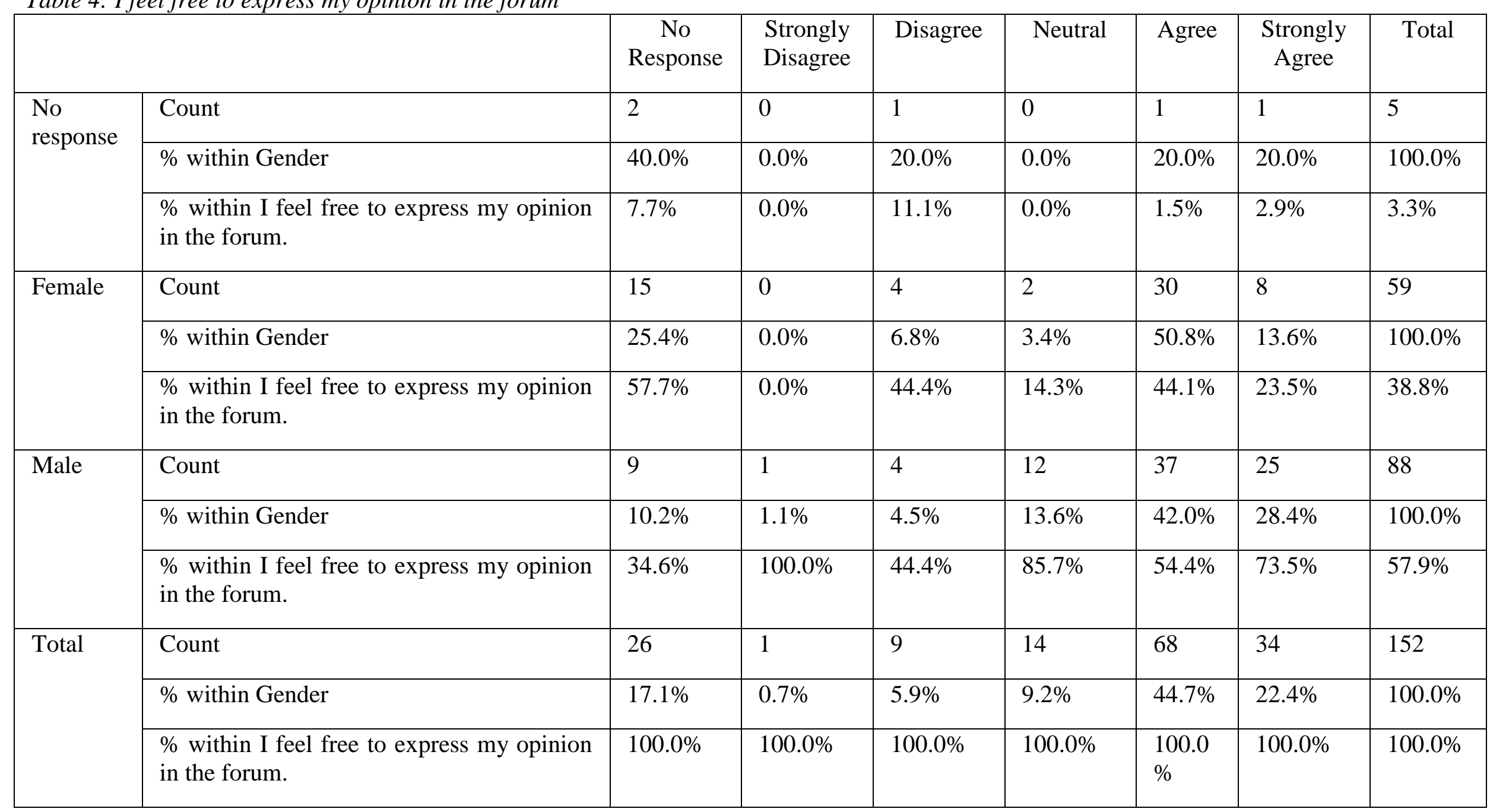

Table 5: There is collective decision making in the forum 


\begin{tabular}{|c|c|c|c|c|c|c|c|c|}
\hline & & $\begin{array}{c}\text { No } \\
\text { Response }\end{array}$ & $\begin{array}{l}\text { Strongly } \\
\text { Disagree }\end{array}$ & Disagree & Neutral & Agree & $\begin{array}{l}\text { Strongly } \\
\text { Agree }\end{array}$ & Total \\
\hline \multirow{2}{*}{$\begin{array}{l}\text { No } \\
\text { response }\end{array}$} & Count & 2 & 0 & 0 & 1 & 1 & 1 & 5 \\
\hline & $\begin{array}{l}\% \text { within There is collective decision } \\
\text { making in the forum. }\end{array}$ & $7.7 \%$ & $0.0 \%$ & $0.0 \%$ & $3.2 \%$ & $1.4 \%$ & $8.3 \%$ & $3.3 \%$ \\
\hline \multirow{2}{*}{ Female } & $\%$ within Gender & $25.4 \%$ & $0.0 \%$ & $10.2 \%$ & $22.0 \%$ & $37.3 \%$ & $5.1 \%$ & $100.0 \%$ \\
\hline & $\begin{array}{l}\% \text { within There is collective decision } \\
\text { making in the forum. }\end{array}$ & $57.7 \%$ & $0.0 \%$ & $50.0 \%$ & $41.9 \%$ & $31.4 \%$ & $25.0 \%$ & $38.8 \%$ \\
\hline Male & Count & 9 & 1 & 6 & 17 & 47 & 8 & 88 \\
\hline \multirow[t]{3}{*}{ Total } & Count & 26 & 1 & 12 & 31 & 70 & 12 & 152 \\
\hline & $\%$ within Gender & $17.1 \%$ & $0.7 \%$ & $7.9 \%$ & $20.4 \%$ & $46.1 \%$ & $7.9 \%$ & $100.0 \%$ \\
\hline & $\begin{array}{l}\% \text { within There is collective decision } \\
\text { making in the forum. }\end{array}$ & $100.0 \%$ & $100.0 \%$ & $100.0 \%$ & $100.0 \%$ & $\begin{array}{l}100.0 \\
\%\end{array}$ & $100.0 \%$ & $100.0 \%$ \\
\hline
\end{tabular}

Table 6: I trust partners to deliver on decisions made by the forum

\begin{tabular}{|l|l|l|l|l|l|c|}
\hline No & Strongly & Disagree & Neutral & Agree & Strongly & Total \\
\hline
\end{tabular}




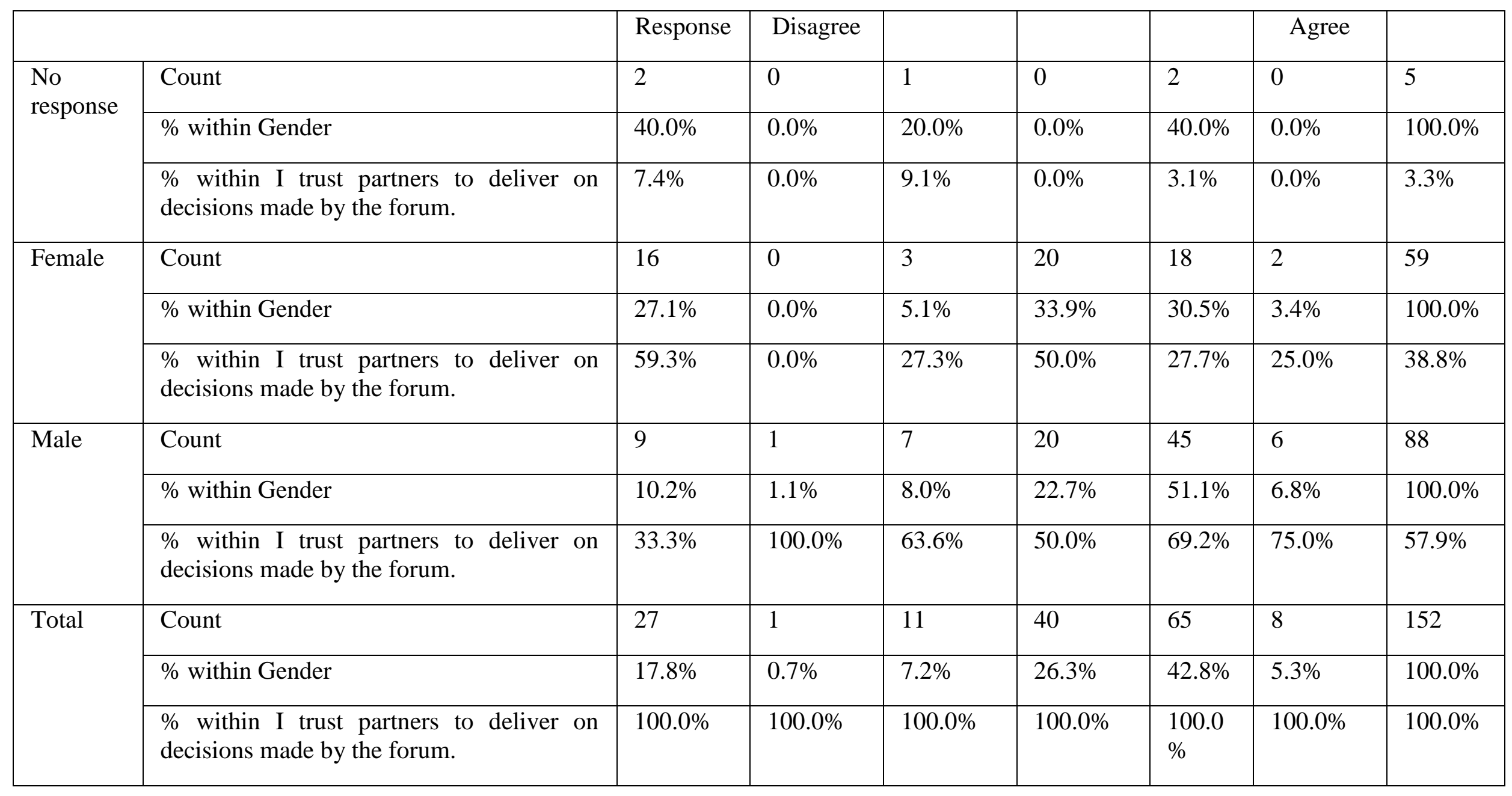

Table 7: Partnerships are efficient and save time as it involves stakeholders from the start of the process

\begin{tabular}{|l|c|c|c|c|c|}
\hline & No Response & Disagree & Neutral & $\begin{array}{c}\text { Agree } \\
\text { Strongly } \\
\text { Agree }\end{array}$ & \begin{tabular}{c} 
Total \\
\hline
\end{tabular}
\end{tabular}




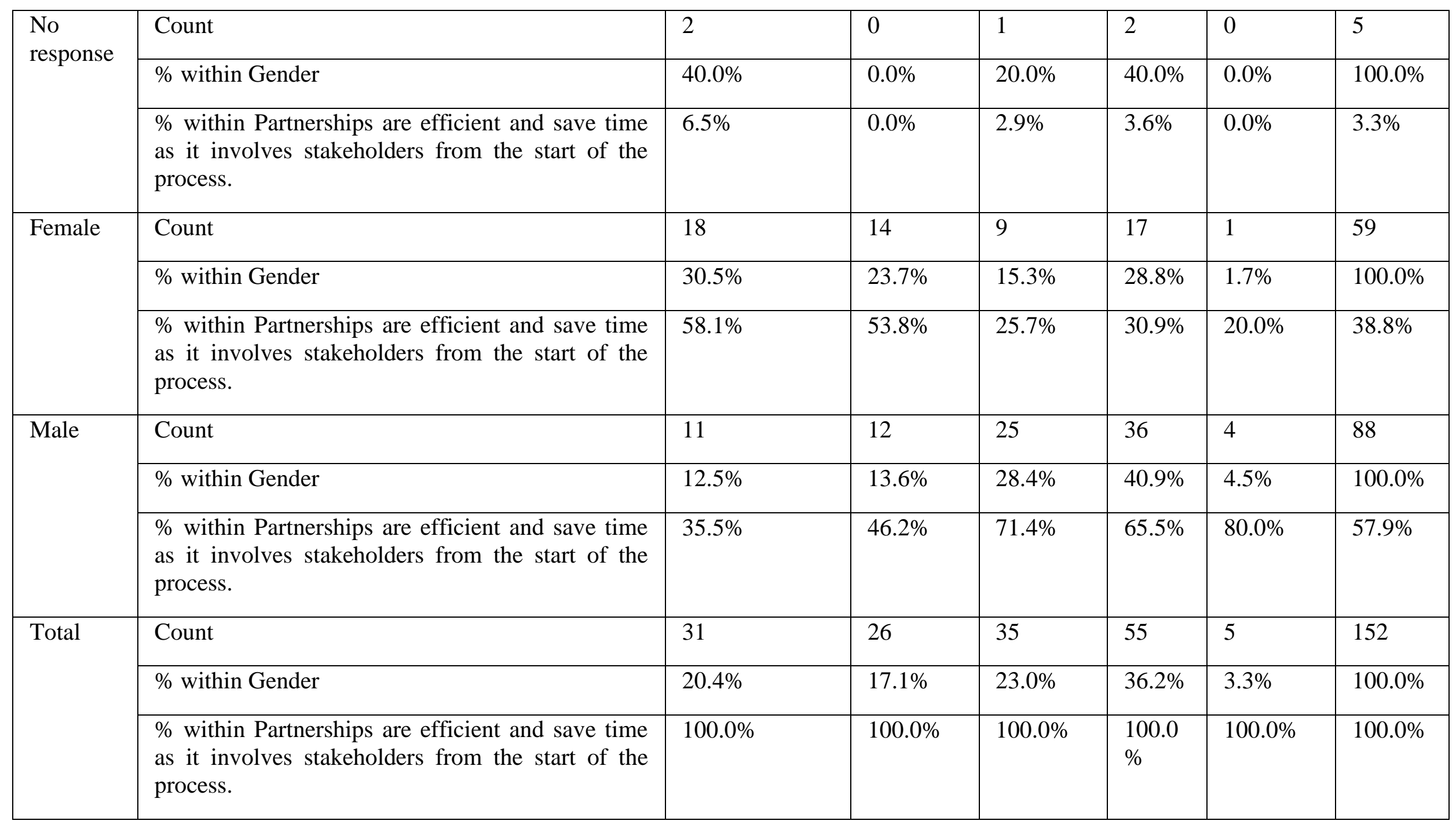

Table 8: Forums allow for opportunities to network and build relationships with partners 


\begin{tabular}{|c|c|c|c|c|c|c|c|c|}
\hline & & $\begin{array}{c}\text { No } \\
\text { Response }\end{array}$ & $\begin{array}{l}\text { Strongly } \\
\text { Disagree }\end{array}$ & Disagree & Neutral & Agree & $\begin{array}{l}\text { Strongly } \\
\text { Agree }\end{array}$ & Total \\
\hline \multirow{3}{*}{$\begin{array}{l}\text { No } \\
\text { response }\end{array}$} & Count & 2 & 0 & 0 & 1 & 1 & 1 & 5 \\
\hline & $\%$ within Gender & $40.0 \%$ & $0.0 \%$ & $0.0 \%$ & $20.0 \%$ & $20.0 \%$ & $20.0 \%$ & $100.0 \%$ \\
\hline & $\begin{array}{l}\% \text { within Forums allow for opportunities to } \\
\text { network and build relationships with partners. }\end{array}$ & $6.5 \%$ & $0.0 \%$ & $0.0 \%$ & $10.0 \%$ & $1.3 \%$ & $3.6 \%$ & $3.3 \%$ \\
\hline \multirow[t]{3}{*}{ Female } & Count & 18 & 1 & 1 & 1 & 25 & 13 & 59 \\
\hline & $\%$ within Gender & $30.5 \%$ & $1.7 \%$ & $1.7 \%$ & $1.7 \%$ & $42.4 \%$ & $22.0 \%$ & $100.0 \%$ \\
\hline & $\begin{array}{l}\% \text { within Forums allow for opportunities to } \\
\text { network and build relationships with partners. }\end{array}$ & $58.1 \%$ & $50.0 \%$ & $100.0 \%$ & $10.0 \%$ & $31.3 \%$ & $46.4 \%$ & $38.8 \%$ \\
\hline \multirow[t]{3}{*}{ Male } & Count & 11 & 1 & 0 & 8 & 54 & 14 & 88 \\
\hline & $\%$ within Gender & $12.5 \%$ & $1.1 \%$ & $0.0 \%$ & $9.1 \%$ & $61.4 \%$ & $15.9 \%$ & $100.0 \%$ \\
\hline & $\begin{array}{l}\% \text { within Forums allow for opportunities to } \\
\text { network and build relationships with partners. }\end{array}$ & $35.5 \%$ & $50.0 \%$ & $0.0 \%$ & $80.0 \%$ & $67.5 \%$ & $50.0 \%$ & $57.9 \%$ \\
\hline \multirow[t]{3}{*}{ Total } & Count & 31 & 2 & 1 & 10 & 80 & 28 & 152 \\
\hline & $\%$ within Gender & $20.4 \%$ & $1.3 \%$ & $0.7 \%$ & $6.6 \%$ & $52.6 \%$ & $18.4 \%$ & $100.0 \%$ \\
\hline & $\begin{array}{l}\% \text { within Forums allow for opportunities to } \\
\text { network and build relationships with partners. }\end{array}$ & $100.0 \%$ & $100.0 \%$ & $100.0 \%$ & $100.0 \%$ & $\begin{array}{l}100.0 \\
\%\end{array}$ & $100.0 \%$ & $100.0 \%$ \\
\hline
\end{tabular}

Table 9: I feel every stakeholder in the forum tries to make decisions which benefit the community /the public in general

\begin{tabular}{|l|l|l|l|l|l|l|l|l|}
\hline & No & Strongly & Disagree & Neutral & Agree & Strongly & Total \\
\hline
\end{tabular}




\begin{tabular}{|c|c|c|c|c|c|c|c|c|}
\hline & & Response & Disagree & & & & Agree & \\
\hline \multirow{3}{*}{$\begin{array}{l}\text { No } \\
\text { response }\end{array}$} & Count & 2 & 0 & 0 & 1 & 2 & 0 & 5 \\
\hline & $\%$ within Gender & $40.0 \%$ & $0.0 \%$ & $0.0 \%$ & $20.0 \%$ & $40.0 \%$ & $0.0 \%$ & $100.0 \%$ \\
\hline & $\begin{array}{l}\text { \% within I feel every stakeholder in the forum } \\
\text { tries to make decisions which benefit the } \\
\text { community/the public in general. }\end{array}$ & $6.3 \%$ & $0.0 \%$ & $0.0 \%$ & $3.8 \%$ & $3.1 \%$ & $0.0 \%$ & $3.3 \%$ \\
\hline \multirow[t]{3}{*}{ Female } & Count & 18 & 1 & 9 & 9 & 18 & 4 & 59 \\
\hline & $\%$ within Gender & $30.5 \%$ & $1.7 \%$ & $15.3 \%$ & $15.3 \%$ & $30.5 \%$ & $6.8 \%$ & $100.0 \%$ \\
\hline & $\begin{array}{l}\text { \% within I feel every stakeholder in the forum } \\
\text { tries to make decisions which benefit the } \\
\text { community /the public in general. }\end{array}$ & $56.3 \%$ & $20.0 \%$ & $64.3 \%$ & $34.6 \%$ & $28.1 \%$ & $36.4 \%$ & $38.8 \%$ \\
\hline \multirow[t]{3}{*}{ Male } & Count & 12 & 4 & 5 & 16 & 44 & 7 & 88 \\
\hline & $\%$ within Gender & $13.6 \%$ & $4.5 \%$ & $5.7 \%$ & $18.2 \%$ & $50.0 \%$ & $8.0 \%$ & $100.0 \%$ \\
\hline & $\begin{array}{l}\text { \% within I feel every stakeholder in the forum } \\
\text { tries to make decisions which benefit the } \\
\text { community /the public in general. }\end{array}$ & $37.5 \%$ & $80.0 \%$ & $35.7 \%$ & $61.5 \%$ & $68.8 \%$ & $63.6 \%$ & $57.9 \%$ \\
\hline \multirow[t]{3}{*}{ Total } & Count & 32 & 5 & 14 & 26 & 64 & 11 & 152 \\
\hline & $\%$ within Gender & $21.1 \%$ & $3.3 \%$ & $9.2 \%$ & $17.1 \%$ & $42.1 \%$ & $7.2 \%$ & $100.0 \%$ \\
\hline & $\begin{array}{l}\text { \% within I feel every stakeholder in the forum } \\
\text { tries to make decisions which benefit the } \\
\text { community /the public in general. }\end{array}$ & $100.0 \%$ & $100.0 \%$ & $100.0 \%$ & $100.0 \%$ & $\begin{array}{l}100.0 \\
\%\end{array}$ & $100.0 \%$ & $100.0 \%$ \\
\hline
\end{tabular}


Table 10: I feel the performance of the partnership forum is monitored by government

\begin{tabular}{|c|c|c|c|c|c|c|c|c|}
\hline & & $\begin{array}{l}\text { No } \\
\text { Response }\end{array}$ & $\begin{array}{l}\text { Strongly } \\
\text { Disagree }\end{array}$ & Disagree & Neutral & Agree & $\begin{array}{l}\text { Strongly } \\
\text { Agree }\end{array}$ & Total \\
\hline \multirow{3}{*}{$\begin{array}{l}\text { No } \\
\text { response }\end{array}$} & Count & 2 & 0 & 1 & 1 & 1 & 0 & 5 \\
\hline & $\%$ within Gender & $40.0 \%$ & $0.0 \%$ & $20.0 \%$ & $20.0 \%$ & $20.0 \%$ & $0.0 \%$ & $100.0 \%$ \\
\hline & $\begin{array}{l}\% \text { within I feel the performance of the partnership } \\
\text { forum is monitored by government. }\end{array}$ & $6.1 \%$ & $0.0 \%$ & $5.9 \%$ & $2.9 \%$ & $1.7 \%$ & $0.0 \%$ & $3.3 \%$ \\
\hline \multirow[t]{3}{*}{ Female } & Count & 18 & 1 & 10 & 12 & 17 & 1 & 59 \\
\hline & $\%$ within Gender & $30.5 \%$ & $1.7 \%$ & $16.9 \%$ & $20.3 \%$ & $28.8 \%$ & $1.7 \%$ & $100.0 \%$ \\
\hline & $\begin{array}{l}\% \text { within I feel the performance of the partnership } \\
\text { forum is monitored by government. }\end{array}$ & $54.5 \%$ & $20.0 \%$ & $58.8 \%$ & $34.3 \%$ & $29.3 \%$ & $25.0 \%$ & $38.8 \%$ \\
\hline \multirow[t]{3}{*}{ Male } & Count & 13 & 4 & 6 & 22 & 40 & 3 & 88 \\
\hline & $\%$ within Gender & $14.8 \%$ & $4.5 \%$ & $6.8 \%$ & $25.0 \%$ & $45.5 \%$ & $3.4 \%$ & $100.0 \%$ \\
\hline & $\begin{array}{l}\% \text { within I feel the performance of the partnership } \\
\text { forum is monitored by government. }\end{array}$ & $39.4 \%$ & $80.0 \%$ & $35.3 \%$ & $62.9 \%$ & $69.0 \%$ & $75.0 \%$ & $57.9 \%$ \\
\hline \multirow[t]{3}{*}{ Total } & Count & 33 & 5 & 17 & 35 & 58 & 4 & 152 \\
\hline & $\%$ within Gender & $21.7 \%$ & $3.3 \%$ & $11.2 \%$ & $23.0 \%$ & $38.2 \%$ & $2.6 \%$ & $100.0 \%$ \\
\hline & $\begin{array}{l}\% \text { within I feel the performance of the partnership } \\
\text { forum is monitored by government. }\end{array}$ & $100.0 \%$ & $100.0 \%$ & $100.0 \%$ & $100.0 \%$ & $100.0 \%$ & $100.0 \%$ & $100.0 \%$ \\
\hline
\end{tabular}

Table 11: There is a high risk to users of the service if the partnership fails to deliver services 


\begin{tabular}{|c|c|c|c|c|c|c|c|c|}
\hline & & $\begin{array}{l}\text { No } \\
\text { Response }\end{array}$ & $\begin{array}{l}\text { Strongly } \\
\text { Disagree }\end{array}$ & Disagree & Neutral & Agree & $\begin{array}{l}\text { Strongly } \\
\text { Agree }\end{array}$ & Total \\
\hline \multirow{3}{*}{$\begin{array}{l}\text { No } \\
\text { response }\end{array}$} & Count & 2 & 0 & 1 & 0 & 2 & 0 & 5 \\
\hline & $\%$ within Gender & $40.0 \%$ & $0.0 \%$ & $20.0 \%$ & $0.0 \%$ & $40.0 \%$ & $0.0 \%$ & $100.0 \%$ \\
\hline & $\begin{array}{l}\% \text { within There is a high risk to users of the } \\
\text { service if the partnership fails to deliver services. }\end{array}$ & $6.3 \%$ & $0.0 \%$ & $7.1 \%$ & $0.0 \%$ & $3.2 \%$ & $0.0 \%$ & $3.3 \%$ \\
\hline \multirow[t]{3}{*}{ Female } & Count & 18 & 0 & 8 & 11 & 20 & 2 & 59 \\
\hline & $\%$ within Gender & $30.5 \%$ & $0.0 \%$ & $13.6 \%$ & $18.6 \%$ & $33.9 \%$ & $3.4 \%$ & $100.0 \%$ \\
\hline & $\begin{array}{l}\% \text { within There is a high risk to users of the } \\
\text { service if the partnership fails to deliver services. }\end{array}$ & $56.3 \%$ & $0.0 \%$ & $57.1 \%$ & $34.4 \%$ & $32.3 \%$ & $18.2 \%$ & $38.8 \%$ \\
\hline \multirow[t]{3}{*}{ Male } & Count & 12 & 1 & 5 & 21 & 40 & 9 & 88 \\
\hline & $\%$ within Gender & $13.6 \%$ & $1.1 \%$ & $5.7 \%$ & $23.9 \%$ & $45.5 \%$ & $10.2 \%$ & $100.0 \%$ \\
\hline & $\begin{array}{l}\% \text { within There is a high risk to users of the } \\
\text { service if the partnership fails to deliver services. }\end{array}$ & $37.5 \%$ & $100.0 \%$ & $35.7 \%$ & $65.6 \%$ & $64.5 \%$ & $81.8 \%$ & $57.9 \%$ \\
\hline \multirow[t]{3}{*}{ Total } & Count & 32 & 1 & 14 & 32 & 62 & 11 & 152 \\
\hline & $\%$ within Gender & $21.1 \%$ & $0.7 \%$ & $9.2 \%$ & $21.1 \%$ & $40.8 \%$ & $7.2 \%$ & $100.0 \%$ \\
\hline & $\begin{array}{l}\% \text { within There is a high risk to users of the } \\
\text { service if the partnership fails to deliver services. }\end{array}$ & $100.0 \%$ & $100.0 \%$ & $100.0 \%$ & $100.0 \%$ & $100.0 \%$ & $100.0 \%$ & $100.0 \%$ \\
\hline
\end{tabular}

Table 12: The partnership forum has given me a better understanding of how to improve policy and service delivery

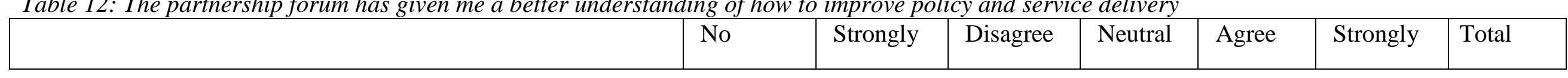




\begin{tabular}{|c|c|c|c|c|c|c|c|c|}
\hline & & Response & Disagree & & & & Agree & \\
\hline \multirow{3}{*}{$\begin{array}{l}\text { No } \\
\text { response }\end{array}$} & Count & 2 & 0 & 0 & 1 & 2 & 0 & 5 \\
\hline & $\%$ within Gender & $40.0 \%$ & $0.0 \%$ & $0.0 \%$ & $20.0 \%$ & $40.0 \%$ & $0.0 \%$ & $100.0 \%$ \\
\hline & $\begin{array}{l}\% \text { within The partnership forum has given me a } \\
\text { better understanding of how to improve policy } \\
\text { and service delivery. }\end{array}$ & $6.3 \%$ & $0.0 \%$ & $0.0 \%$ & $3.3 \%$ & $2.8 \%$ & $0.0 \%$ & $3.3 \%$ \\
\hline \multirow[t]{3}{*}{ Female } & Count & 18 & 1 & 3 & 15 & 19 & 3 & 59 \\
\hline & $\%$ within Gender & $30.5 \%$ & $1.7 \%$ & $5.1 \%$ & $25.4 \%$ & $32.2 \%$ & $5.1 \%$ & $100.0 \%$ \\
\hline & $\begin{array}{l}\% \text { within The partnership forum has given me a } \\
\text { better understanding of how to improve policy } \\
\text { and service delivery. }\end{array}$ & $56.3 \%$ & $50.0 \%$ & $37.5 \%$ & $50.0 \%$ & $26.4 \%$ & $37.5 \%$ & $38.8 \%$ \\
\hline \multirow[t]{3}{*}{ Male } & Count & 12 & 1 & 5 & 14 & 51 & 5 & 88 \\
\hline & $\%$ within Gender & $13.6 \%$ & $1.1 \%$ & $5.7 \%$ & $15.9 \%$ & $58.0 \%$ & $5.7 \%$ & $100.0 \%$ \\
\hline & $\begin{array}{l}\% \text { within The partnership forum has given me a } \\
\text { better understanding of how to improve policy } \\
\text { and service delivery. }\end{array}$ & $37.5 \%$ & $50.0 \%$ & $62.5 \%$ & $46.7 \%$ & $70.8 \%$ & $62.5 \%$ & $57.9 \%$ \\
\hline \multirow[t]{3}{*}{ Total } & Count & 32 & 2 & 8 & 30 & 72 & 8 & 152 \\
\hline & $\%$ within Gender & $21.1 \%$ & $1.3 \%$ & $5.3 \%$ & $19.7 \%$ & $47.4 \%$ & $5.3 \%$ & $100.0 \%$ \\
\hline & $\begin{array}{l}\% \text { within The partnership forum has given me a } \\
\text { better understanding of how to improve policy } \\
\text { and service delivery. }\end{array}$ & $100.0 \%$ & $100.0 \%$ & $100.0 \%$ & $100.0 \%$ & $100.0 \%$ & $100.0 \%$ & $100.0 \%$ \\
\hline
\end{tabular}


Table 13: My participation adds legitimacy to decisions made by the forum

\begin{tabular}{|c|c|c|c|c|c|c|c|c|}
\hline & & $\begin{array}{l}\text { No } \\
\text { Response }\end{array}$ & $\begin{array}{l}\text { Strongly } \\
\text { Disagree }\end{array}$ & Disagree & Neutral & Agree & $\begin{array}{l}\text { Strongly } \\
\text { Agree }\end{array}$ & Total \\
\hline \multirow{3}{*}{$\begin{array}{l}\text { No } \\
\text { response }\end{array}$} & Count & 2 & 0 & 0 & 0 & 3 & 0 & 5 \\
\hline & $\%$ within Gender & $40.0 \%$ & $0.0 \%$ & $0.0 \%$ & $0.0 \%$ & $60.0 \%$ & $0.0 \%$ & $100.0 \%$ \\
\hline & $\begin{array}{l}\% \text { within My participation adds legitimacy to } \\
\text { decisions made by the forum. }\end{array}$ & $6.1 \%$ & $0.0 \%$ & $0.0 \%$ & $0.0 \%$ & $4.5 \%$ & $0.0 \%$ & $3.3 \%$ \\
\hline \multirow[t]{3}{*}{ Female } & Count & 18 & 1 & 3 & 14 & 19 & 4 & 59 \\
\hline & $\%$ within Gender & $30.5 \%$ & $1.7 \%$ & $5.1 \%$ & $23.7 \%$ & $32.2 \%$ & $6.8 \%$ & $100.0 \%$ \\
\hline & $\begin{array}{l}\text { \% within My participation adds legitimacy to } \\
\text { decisions made by the forum. }\end{array}$ & $54.5 \%$ & $100.0 \%$ & $33.3 \%$ & $50.0 \%$ & $28.8 \%$ & $26.7 \%$ & $38.8 \%$ \\
\hline \multirow[t]{3}{*}{ Male } & Count & 13 & 0 & 6 & 14 & 44 & 11 & 88 \\
\hline & $\%$ within Gender & $14.8 \%$ & $0.0 \%$ & $6.8 \%$ & $15.9 \%$ & $50.0 \%$ & $12.5 \%$ & $100.0 \%$ \\
\hline & $\begin{array}{l}\% \text { within My participation adds legitimacy to } \\
\text { decisions made by the forum. }\end{array}$ & $39.4 \%$ & $0.0 \%$ & $66.7 \%$ & $50.0 \%$ & $66.7 \%$ & $73.3 \%$ & $57.9 \%$ \\
\hline \multirow[t]{3}{*}{ Total } & Count & 33 & 1 & 9 & 28 & 66 & 15 & 152 \\
\hline & $\%$ within Gender & $21.7 \%$ & $0.7 \%$ & $5.9 \%$ & $18.4 \%$ & $43.4 \%$ & $9.9 \%$ & $100.0 \%$ \\
\hline & $\begin{array}{l}\% \text { within My participation adds legitimacy to } \\
\text { decisions made by the forum. }\end{array}$ & $100.0 \%$ & $100.0 \%$ & $100.0 \%$ & $100.0 \%$ & $100.0 \%$ & $100.0 \%$ & $100.0 \%$ \\
\hline
\end{tabular}

Table 14: I feel that I make a real difference to improving the delivery of services in my community 


\begin{tabular}{|c|c|c|c|c|c|c|c|c|}
\hline & & $\begin{array}{l}\text { No } \\
\text { Response }\end{array}$ & $\begin{array}{l}\text { Strongly } \\
\text { Disagree }\end{array}$ & Disagree & Neutral & Agree & $\begin{array}{l}\text { Strongly } \\
\text { Agree }\end{array}$ & Total \\
\hline \multirow{3}{*}{$\begin{array}{l}\text { No } \\
\text { response }\end{array}$} & Count & 3 & 0 & 0 & 0 & 2 & 0 & 5 \\
\hline & $\%$ within Gender & $60.0 \%$ & $0.0 \%$ & $0.0 \%$ & $0.0 \%$ & $40.0 \%$ & $0.0 \%$ & $100.0 \%$ \\
\hline & $\begin{array}{l}\text { \% within I feel that I make a real difference to } \\
\text { improving the delivery of services in my } \\
\text { community. }\end{array}$ & $8.8 \%$ & $0.0 \%$ & $0.0 \%$ & $0.0 \%$ & $3.3 \%$ & $0.0 \%$ & $3.3 \%$ \\
\hline \multirow[t]{3}{*}{ Female } & Count & 18 & 2 & 2 & 15 & 17 & 4 & 58 \\
\hline & $\%$ within Gender & $31.0 \%$ & $3.4 \%$ & $3.4 \%$ & $25.9 \%$ & $29.3 \%$ & $6.9 \%$ & $100.0 \%$ \\
\hline & $\begin{array}{l}\text { \% within I feel that I make a real difference to } \\
\text { improving the delivery of services in my } \\
\text { community. }\end{array}$ & $52.9 \%$ & $100.0 \%$ & $16.7 \%$ & $46.9 \%$ & $28.3 \%$ & $36.4 \%$ & $38.4 \%$ \\
\hline \multirow[t]{3}{*}{ Male } & Count & 13 & 0 & 10 & 17 & 41 & 7 & 88 \\
\hline & $\%$ within Gender & $14.8 \%$ & $0.0 \%$ & $11.4 \%$ & $19.3 \%$ & $46.6 \%$ & $8.0 \%$ & $100.0 \%$ \\
\hline & $\begin{array}{l}\text { \% within I feel that I make a real difference to } \\
\text { improving the delivery of services in my } \\
\text { community. }\end{array}$ & $38.2 \%$ & $0.0 \%$ & $83.3 \%$ & $53.1 \%$ & $68.3 \%$ & $63.6 \%$ & $58.3 \%$ \\
\hline \multirow[t]{3}{*}{ Total } & Count & 34 & 2 & 12 & 32 & 60 & 11 & 151 \\
\hline & $\%$ within Gender & $22.5 \%$ & $1.3 \%$ & $7.9 \%$ & $21.2 \%$ & $39.7 \%$ & $7.3 \%$ & $100.0 \%$ \\
\hline & $\begin{array}{l}\text { \% within I feel that I make a real difference to } \\
\text { improving the delivery of services in my } \\
\text { community. }\end{array}$ & $100.0 \%$ & $100.0 \%$ & $100.0 \%$ & $100.0 \%$ & $100.0 \%$ & $100.0 \%$ & $100.0 \%$ \\
\hline
\end{tabular}


